able from: Ktav Publishing House, Inc., 75 Varick St. [431 Canal St.], New York, NY 10013.)

Since its inception in 1947, the American Jewish Archives (AJA) at Hebrew Union College in Cincinnati has become the focal point for documenting the history of American Jews.

Jacob R. Marcus, the archives' first director, writes in the foreword to the Guide that the volume is to enable researchers to gain an idea of the scope and variety of material in the American Jewish Archives and is intended especially for those who do not have ready access to the AJA's five-volume Manuscript Catalog.

The Guide is divided into four sections: manuscript collections; microfilms from other repositories; theses, dissertations, and essays; and special files. Manuscript collections comprise the largest part. Among the unusual holdings: a petition to appoint a Jewish chaplain in the Union Army; a genealogical record from Utah that traces a family's ancestry "theoretically" to King David; the papers of Sophie Tucker (no doubt stored in asbestos-lined boxes); and, of course, the records of now-forgotten early immigrants (peddlers, tailors, Indian traders) as well as prominent professionals and merchant princes.

Researchers will value the section devoted to local records. Here are listed the constitutions, minutes, and membership and burial records from scattered congregations in the Caribbean beginning in the early 1600 s and the first congregation in New Amsterdam (New York City) founded by those fleeing the Inquisition in Brazil. One is struck by the number of far-flung synagogues established in the early United States: Savannah, Georgia (1790); Charleston, South Carolina (1800); New Orleans, Louisiana (1829).

One-half of the Guide consists of seven appendixes and an index; however, not all the names in the appendixes appear in the index. The failure to identify the people listed in the biographies and correspondence files limits their value as finding aids. This becomes apparent when we are confronted by such common Jewish names as Charles Goldberg, Henry Mayer, Samuel Rosenblum, Jacob Cohen. The names may be familiar to specialists in American Jewish history, but how is an undergraduate to know them?

A list of abbreviations would have avoided the necessity of spelling out with regular monotony such long names as Hebrew Union College-Jewish Institute of Religion. The same applies to the names of the various states of the union.

The researcher is left wondering why the Bernard M. Baruch file is only 0.3 inches thin or why Sol Bloom, who served twenty-six years in the U.S. Congress, has only eight thin folders. In the published Manuscript Catalog an inserted reference informs the reader that the major Baruch collection is at City College Library, New York City (Bloom's is at the New York Public Library). Such notes at critical places would have answered questions arising in the investigator's mind.

Most of the typographical errors occur in German names (e.g., $e i$ and $i e$ ). This is regrettable, since so many Jewish names are of German origin.

Confronted by more than six million pieces in the AJA, the editors have given us a limited sampling, and while they do not explain the basis for selecting material to be included, it appears that the major collections are present and edited into succinct entries. For libraries not possessing the Manuscript Catalog, the Guide serves only to stimulate the researcher's interest to the entire collection.-Kurt S. Maier, Washington, D.C.

Stineman, Esther. Women's Studies: A Recommended Core Bibliography. With the assistance of Catherine Loeb. Littleton, Colo.: Libraries Unlimited, 1979. 670p. $\$ 27.50$ U.S. and Canada; $\$ 33$ elsewhere. LC 79-13679. ISBN 0-87287-196-7.

Williamson, Jane. New Feminist Scholarship: A Guide to Bibliographies. Old Westbury, N.Y.: The Feminist Press, 1979. 139p. \$15. LC 79-11889. ISBN 0-912670-54-1.

Women's Studies is a massive undertaking that lists over 1,700 items to support women's studies programs. The annotations, given for all items except periodical articles or special issues, are critical as well as descriptive and often cite other items. The inclusion of price, ISBN, and/or LC card number renders this bibliography invaluable 
for those in acquisitions or collection development. Out-of-print items are included also.

Arrangement is by twenty-six broad categories such as "Autobiography, Biography, Diaries, Memoirs, Letters"; "Medicine, Health, Sexuality, Biology"; and "Women's Movement and Feminist Theory." Each section is alphabetic by author. There are author and title indexes that include items cited within the annotations; and the subject index has excellent see and see also references.

The introduction mentions nontraditional materials, but the listings are limited to the traditional print medium. The usefulness of Women's Studies would have been expanded significantly if other media were included. While no bibliography can be allinclusive, there are some omissions that one wonders about. Three journals and three novels by May Sarton are listed, but neither her Collected Poems (1930-1973) (Norton, 1974) nor Selected Poems of May Sarton (Norton, 1978) is listed. Other missing citations are Ira B. Bryant, Barbara Charlene Jordan: From the Ghetto to the Capitol (D. Armstrong, 1977); Marie Bowes, Female Artists, Past and Present (Women's History Research Center, 1972); and all the Herstory microfilm collections, to mention only a few. Women's Studies is a most welcome tool, and the omissions do not detract greatly from its usefulness.

Williamson's New Feminist Scholarship presents almost 400 entries for Englishlanguage bibliographies, both separately published works and articles, and includes out-of-print items. Excluded are brief reading lists, nonsexist books for children and young adults, literary bibliographies of individual women writers, and bibliographies that are parts of monographs or anthologies.

Arrangement is by broad subjects: criminal justice, life cycles, sex roles and sex differences, women's movement. Introductory paragraphs outline the scope of each section, and there are cross-references to related sections. However, if one has gone first to the "Women and Development" section, one finds no reference to "see also Economics," whereas under "Economics" is a reference to "see also Women and Development." Within each of the thirty categories entries are alphabetized by au- thor. Slightly more than half of the citations are descriptively annotated.

There are author and title indexes, and a list of publishers' addresses is given.

Williamson might have included several works that Stineman lists: Carol Hollenshead, Past Sixty: The Older Woman in Print and Film (Institute of Gerontology, University of Michigan-Wayne State University, 1977); Shreemati Nathibai Damodar Thackersey Women's University, Bombay. Research Unit on Women's Studies, A Select Bibliography on Women in India (Allied Publishers; dist. by South Asia Books, 1976); and Joann Skowronski, Women in American Music: A Bibliography.

New Feminist Scholarship offers the researcher or instructor in women's studies a fairly comprehensive accounting of the standard bibliographies. Librarians involved in collection development or acquisitions would have been better served with the addition of prices and bibliographic identification by ISBN and/or LC card number.

Together these two bibliographies provide excellent guidance for research and collection development in the increasingly popular area of women's studies.-Jeanette Mosey, OCLC Western, San Francisco, California.

\section{Proceedings of the American Studies Li-} brary Conference. Held at the U.S. Embassy, London, 16 and 17 February 1978. Edited by Peter Snow. Oxford, England: American Studies Library Group, 1979. 13lp. £2.50. ISBN 0-9506448-0-3. Available from: Iain Wallace, John Rylands University Library of Manchester, Oxford Rd., Manchester, England.

In an age when most librarians must cope with budgets shrinking from the pressures of inflation and/or legislative shortsightedness, it is refreshing to read of problems caused by an unsatiated appetite for materials on a specific subject. Such was the general tenor of the American Studies Library Conference held at the U.S. Embassy in London on February 16-17, 1978.

At the conclusion of the conference participants moved to organize an American Studies Library Group in order to aid in the solution of problems connected with acquiring American studies materials from across the Atlantic. The motion was the culmina- 